Mariana Sedliacikova,

Ph.D., Associate Professor, Technical University in Zvolen, Slovakia

Anna Kocianova,

Technical University in Zvolen, Slovakia

Michal Dzian,

Ph.D., Technical University in Zvolen, Slovakia

Josef Drabek,

Associate Professor, Technical University in Zvolen, Slovakia

\title{
PRODUCT SAMPLING AS A SALE PROMOTION TOOL
}

Abstract. Product sampling in the retail chains relates to marketing, it makes part of the in-store marketing, and it is one of the sale promotion tools. It used to promote the sales of non-durable products, i.e. food. The paper aimed to find out how it is perceived by customers of retail chains (consumers) in Slovakia. An essential aspect of the sampling effectiveness was verified, namely the addressing of potential customers by the promoters. The article focused on ethical practices during the samplings. The subject of interest was to confirm whether promoters keep basic ethical and moral principles. The repeated request for sampling was one of the points. The vital aspect of the sampling ethics was also considered as well as the truthfulness of customer responses to promoter questions about the taste of the product. The sampling ethics was judged from both viewpoints of the sampling participants. The questionnaire survey was carried out to meet the goal, and the sampling participants were addressed. The online questionnaire method was applied, in which 484 respondents were directed. The survey results have shown that customers perceive samplings positively. Sampling has found its application in Slovakia, and it is a relatively accessible tool for promotion of sales (also from the viewpoint of producers). The promoter is the major contributor to the number of participating customers. The main aspects influencing the level of sampling ethics are the age and gender of the customers. It is believed that at any time, it is appropriate to verify the ethics of one of the sales promotion tools - sampling, and at the same time to find out how customers perceive it. The paper contributes to the area of instore marketing. It brings findings focused on the popularity of the sampling in practice, purchasing habits of the customers, and at the same time, it opens a space for further improvements.

Keywords: sampling, sampling perception, sampling ethics, customers, promoters.

Introduction. The role of the food samplings in the retail chains is the physical presence of the product. They enable to influence the senses of a person (namely touch, smell, taste and sight) into the customer's interaction with the product being promoted. In recent decades, researchers' interest in sales promotion, including sampling, has increased (Amor and Guilbert, 2015). Despite the increased attention, there are still many areas that have not been sufficiently explored (Bawa and Shoemaker, 2004; Heimanet et al., 2001). One of them is the perception of sampling from the perspective of customers and the level of sampling ethics in practice. The presented study focuses on these points.

Samplings offer the opportunity to try (taste) a product that customers might not usually buy immediately at the time of promotion. The samplings give the producers a chance to present the quality of their products directly in front of customers (Biswas et al., 2014). Danaher (2017) and Hein (2009) state that sampling is the most efficient tool on how to reach that customers would try a new product. Sampling is a targeted sales promotion process defined by the underlying concept (Biswas et al., 2010; Hein, 2009). Unwanted situations can often occur when a customer interacts with a promoter. These lead to a breach of the concept of responsible marketing. Responsible marketing is one of the critical elements of success in business (Boulstridge and Carrigan, 2000; Carrigan and Attalla, 2001). The concept of responsible marketing at sampling can be disrupted in situations when the promoter explicitly asks for customer participation despite their initial rejection or when the developer affects the customer in purchasing decisions. Not only these aspects but also the perception of samplings by customers affects the overall

Cite as: Sedliacikova, M., Kocianova, A., Dzian, M., Drabek, J. (2020). Product Sampling as a Sales Promotion Tool. Marketing and Management of Innovations, 1, 136-148. http://doi.org/10.21272/mmi.2020.1-11 
sampling ethical level. For these reasons, the paper aims to determine the understanding of sampling from the perspective of customers and the level of sampling ethics in practice. It is assumed that the level of sampling ethics is linked to the perception of sampling by customers, and therefore the two areas were joined in this paper. A questionnaire survey was conducted to prove or disprove the assumed claims about the popularity of sampling and the level of its ethics in practice in the part Methodology and research methods.

Literature Review. Sampling is an essential promotional tool designed to catch the attention of customers (and consumers in one) and make purchasing decisions by physical presentation of the promoted product (Chen et al., 2016). It forms part of marketing, and it is one of the sales promotion tools. As promoters providing products to taste are an essential part of the sampling, it is considered to be a humanized sales promotion. The article takes into consideration the sampling of non-durable food products directly in the stores and retail. Therefore the subject area is the in-store marketing (Jesensky et al., 2017; Hein, 2009; Biswas et al., 2014).

The importance of in-store marketing is that most purchasing decisions are made directly at the point of sale, in the store. Approximately two-thirds of purchasing decisions are influenced at the end of the auction by some of the following factors: price discounts, in-store promotion - including sampling, the atmosphere in the shop, distribution of sales area, service provided, sell-off of stock and eye-catchers (Fam et al., 2011; Dawes, 2002; Alvarez and Vazquez, 2005). The significance of the purchasing decisions at the point of sale is enormous and provides a space for further development for the retailers (Fam et al., 2011).

The food industry is one of the leading employers worldwide. Marketing strategies applied in the food industry concern many people, influence the price, quantity and quality of foodstuff. Marketing itself allows customers to make purchasing decisions based on the provided information. It brings together producers, sellers and customers into one unit (Sadiku et al., 2019; Range and Leaonard, 2016).

In the time of survey of the sampling effect on the behaviour of the consumers, McGuinness et al. (1995) defined sampling as a supporting promotion tool, through which sellers can influence the consumer purchasing decisions. To complement the complexity, Hein (2009) states that this sales promotion tool involves "handing out" a specified amount of products to low-risk and non-committed customers. Haiman et al. (2001) concluded that sampling could affect the perception of feminized products in male perception with both short and long term effects of efficiency. At the same time, sampling is a mean how to offer customers something extra and notably free of charge (Notte, 2011; Laran and Tsiros, 2013).

In the last two decades, supermarkets have become the central place of purchase $(\mathrm{He}, 2005$; Chen, 2013). Their success is driven by customer loyalty, which stems from various methods and tools of sales support and promotion. It is also derived from the targeted impact on customer purchasing decisions, especially valid for price-sensitive customers (McNeill, 2006; Chen, 2013). The efficiency and success of supermarkets are based on two fundamental elements, advertising and sales promotion (Buil et al., 2013). Food advertising helps build a brand image. It consists of oral communication (or sampling - via a promoter) and should be accompanied by high costs in the form of promotions, discounts, etc. (Hawkes, 2008; Chen, 2013; Buil et al., 2013).

Lammers (1991) defined the main objective of tastings to raise consumer awareness of a particular product. Sampling can persuade a consumer to buy a product through a sensory product test before the purchase itself. At the same time, it helps build a positive perception of the brand, improves the product awareness at the point of sale and particularly, it leads customers to repeated purchasing, what in return applies the loyalty effect (Heilman et al., 2011; Chandon et al., 2000; Chen et al., 2016; Alvarez and Vazquez, 2005). In addition to the above mentioned, the synergic effect applies, through increasing of interest in the offered product can lead to the increase of interest in similar products in the series, 
assortment and the like, what causes the growth of the market and its image (Fam et al., 2011; Bawa and Shoemaker, 2004).

In recent years, there has been a rapid increase of interest in sampling by customers, sellers, as well as producers (Jesensky et al., 2017; Chen et al., 2016). The elaborated overview of problem-solving shows a broad interest in the topic. Still, there is a significant gap in the examination of sampling ethics by sampling executors - promoters and customers. In addition to building the image, loyalty and promotion of the product, the aim of sampling is practically the knowledge about the market and needs of customers. Their preferences and interests regulate the requirements that must be implemented in the product function (flavours, new product variations, and the like.) so that producers achieve success (Jesensky et al., 2017). The objective of the sampling is not only to influence the purchasing decisions but also gain popularity at the customers.

Individual aspects are closely interrelated, and the popularity of sampling at costumers is linked to the level of sampling ethics. The critical element is the proper promoter (Jesensky et al., 2017; Bocek et al., 2000).

At present, responsible marketing is one of the critical attributes of a successful business (Kim, 2019). Responsible marketing is a means of sustainable success of the producers on the market and subsequent development (Meler and Dragan, 2014; Mandal and Banerjee, 2018). Within the topic of sampling and examination of its ethical principles as well as customer perception, the communication factor of social responsibility is significant that is manifested during the sampling itself. Social responsibility is closely related to responsible marketing (Meler and Dragan, 2014; Seretny and Seretny, 2012). In this case, the promoter plays a significant role who bears responsibility during the sampling. Three essential aspects meet in this issue: responsible marketing, social responsibility and the person of the promoter. Enterprises that have been working on their brand through a popular product for long years cannot risk that an irresponsible employee (promote) would undermine their efforts. They have to attract a quality workforce and talented people who can make the sampling even more attractive for the customers and provide their high ethical level (Aggerholm et al., 2011; Vetrakova et al., 2018).

The topic of the paper concerns also ethics in marketing. Ethics in marketing deals with moral principles that accompany all individual operations in the marketing process. Its importance has been growing at a dynamic pace in recent decades (Sadiku et al., 2019). It is due to the findings of individual enterprises that ethical problems can disrupt the image and reputation of the business. Trust and customer relationships are as crucial to success as any other area of management. The impact of the ethic on the success of the enterprise should not be underestimated. Ethics is closely related to social responsibility. By following ethical principles, an enterprise will likely become socially responsible. To be ethic means to do what is right and does not harm the interested parties (Ferrell and Hartline, 2007; Brinkmann, 2002). Initially, targeted ethical behaviour of enterprises can be costly. As a result of time, there is a synergic effect, which leads to strengthening the reputation of the enterprise. It provokes further responses to the competition. Customer action in these cases will not wait long and will manifest in the growth of satisfaction with the product and enterprise as a whole (Pride and Ferrell, 2006; Brinkmann, 2002; Ferrell and Hartline, 2007).

Methodology and research methods. According to Kozel (2006), the process of marketing survey consists of a preparatory and an implementation phase. Individual phases include several steps, while the important ones are stated further in detail.

The preparatory phase consists of defining the problem and the objective and orientation analysis of the situation and the plan of the surveying project. The implementation phase consists of data collection, processing of collected data, data analysis, interpretation of survey results and final report together with their presentation. 
The examined problem is the level of sampling ethics in practice and its perception by customers. The paper aims to verify the decent level of sampling in practice and to find out how it is perceived by customers when interacting with the promoter. A questionnaire survey was conducted, which addressed the sampling participants to meet the stated goal.

The questionnaire consisted of nineteen questions, while the first four were identification questions (gender, age, region, education). Before the identification questions, a filter question was placed on whether the person had ever attended a sampling (if the condition was not met, a redirection to thank-you happened). Other questions concerned the subject matter of the paper, i.e. the sampling perception by customer and ethics during the sampling. The part about sampling perception built upon the customer decides to stop or not at the sampling stand in case they spot it in the shop. In the part sampling ethics, the view of the repeated requests of the promoters to taste was exciting, the pressure to buy the sampled product. At the question about the taste, it was examined whether the customers answer truthfully in case they did not like the product. Questionnaire data collection occurred online through a Google form during the period from November 2018 to March 2019. The questionnaire was placed on various social networks.

The sample size was determined using a mathematical relationship designed to calculate the minimum number of respondents involved in the survey:

$$
\mathrm{n} \geq \frac{\left(\mathrm{z}^{2} \times \mathrm{p} \times \mathrm{q}\right)}{\Delta^{2}}
$$

The minimum number of respondents in the formula is represented by letter $n$; the quantity $z$ represents the reliability coefficient; quantities $p$ and $q$ show the percentage of respondents who know or do not know about the issue, or who participated or did not participate in sampling in the markets. The choice of respondents was random, and their participation in sampling was unknown, so it was necessary to divide the sample of respondents in half so that the product of $p$ and $q$ values is maximal, i.e. $50 \%$ to $50 \%$. The value represented by $\Delta$ means the maximum permissible significant error (Kozel, 2006).

For higher reliability of the research $(95 \%)$, the value of the $z$ was stated as $z=2$. The maximum error value for a representative sample was set at $5 \%$. By substituting the individual values into the formula, the minimum number of respondents for the reliability of the research was determined (Kozel, 2006):

$$
\mathrm{n}=\frac{2^{2} \times 0,5 \times 0,5}{0,05^{2}}
$$

The sample size should have consisted of at least 400 respondents so that the research was $95 \%$ reliable. The return rate of the questionnaires was at the level of 484 completed questionnaires. Subsequently, the obtained data were processed and analysed by Pearson's chi-square test, which is the most widely used independence test. In this way, the independence or dependence of the monitored variables (demographic signs) concerning the asked questions was determined. The null hypothesis is the assertion that mutually tested variables are independent, i.e. certain variations of $x$ variable do not affect certain variations of $y$ variable. The test is based on the idea of comparing the numbers of expected and real values. The test characteristic of the Chi-square test is as follows:

$$
\chi^{2}=\sum_{i=1}^{k} \frac{\left(X_{i}-N p_{i}\right)^{2}}{N p_{i}}
$$

Following hypotheses were tested at the significance level of $5 \%$, i.e. a (alfa) $=0,05$ (Note: majority means at least $50 \%$ of respondents): 

more).

$\mathrm{H} 1=\mathrm{It}$ is assumed that the majority of the respondents perceive sampling positively (scale 4 and

$\mathrm{H} 2=$ It is assumed that the majority of customers stop at sampling after addressing by the promoter.

$\mathrm{H} 3=\mathrm{It}$ is assumed that the majority of customers do not stop at sampling in case not being addressed by the promoter.

$\mathrm{H} 4=$ It is assumed that the majority of respondents were not forced by the promoter to taste the product when they once refused.

$\mathrm{H} 5=\mathrm{It}$ is assumed that the majority of respondents were not pressured by the promoter to buy the tasted product.

$\mathrm{H} 6=$ It is assumed that the majority of respondents answer truthfully on the question about the product taste.

The results of the questionnaire survey were also processed by descriptive statistics and evaluated using tables. To keep the work clear, only those dependencies that are considered the most important for the job were taken out from the Chi-square test. Altogether six questions were evaluated, the answers to the first question (Q1) had to be marked on the Likert scale 1-5 (1 very negative to 5 very positive). The Likert scale was used to express the attitude of the customers and their preferences to the sampling placed in the store. The other questions were marked with a yes / no choice based on the nature of the issue.

Results. The results are presented in the way to keep the objective of the paper, i.e. in two parts sampling perception by customers and sampling ethics. In the area of the sampling perception by the customer, the main focus was to monitor in what extent customers perceive sampling and whether they decide to participate or not when being addressed or not by the promoter. The following questions were asked in this issue:

Q1: When you see a sampling stand the shop, how do you perceive it on the scale from 1 to 5 ?

This question is related to the hypothesis $\mathrm{H} 1$ that was formulated based on the affirmations of authors Kotler et al. (2007) and Jesensky et al. (2017). According to these authors, sampling is very popular by customers and producers, however less popular by sellers or retail chains. By Vysekalova et al. (2014), who investigated how the Czech public accepted sampling, the customers received it positively, and it is trendy there. One-third of the adult population would even welcome more sampling promotions in the retail stores.

Respondents answered the question on the scale four and more in the number of 267 , which presents $55.17 \%$. Based on this data, the hypothesis $\mathrm{H} 1$ has been confirmed, that in most cases, customers really like sampling and perceive it positively. $35.74 \%$ of respondents expressed a neutral attitude, and only $9.09 \%$ of respondents expressed an opinion that they view sampling negatively - scale two and less (Table 1).

Table 1. Answers of the customers (Q1)

\begin{tabular}{|c|c|}
\hline Type of response on question No. 1 & Number of answers \\
\hline Very negative & 13 \\
\hline Rather negative & 31 \\
\hline Neither negative nor positive & 173 \\
\hline Rather positive & 113 \\
\hline Very positive & 154 \\
\hline
\end{tabular}

Sources: own editing based on primary data collection.

It is considered that there is a relatively high percentage of neutral respondents who probably have no unique experience with sampling but on the contrary, neither negative. It is an opportunity for producers and sellers to find new ways of sampling, how to catch the attention of customers and make sampling 
more attractive. On the other hand, these respondents can quickly move to the opposite side. For example, in the case of breaches of ethics by promoter or pressure or different negative experience, they quickly turn their perception to negative.

Q2: In case you pass a sampling stand in a store and the promoter address you, what do you usually do?

This question is assigned to the hypothesis $\mathrm{H} 2$, which was similar to hypothesis $\mathrm{H} 1$ formulated based on the authors Kotler et al. (2007), Jesensky et al. (2017) and Vysekalova et al. (2014). Based on the assumption that customers like sampling (as confirmed by hypothesis $\mathrm{H} 1$ ), they like to come along if the promoter addresses them.

The hypothesis $\mathrm{H} 2$ has been confirmed because the majority of the respondents stop at the stand with sampling when the promoter addresses them. $67.77 \%$ of respondents responded positively. $32.23 \%$ of respondents expressed negatively. They do not stop at the position even though the promoter directs them. (Table 2).

Table 2. Answers of the customers (Q2)

\begin{tabular}{|c|c|}
\hline Type of response on question No. 2 & Number of answers \\
\hline I stop & 328 \\
\hline I do not stop & 156 \\
\hline
\end{tabular}

Sources: own editing based on primary data collection.

Q3: On the contrary, if you pass a sampling stand in the store and the promoter does not address you, what do you usually do?

Through the question (Q3), the hypothesis $\mathrm{H} 3$ is confirmed or disproved. This hypothesis follows the hypothesis $\mathrm{H} 2$, focusing in detail on the difference in the condition of the absence of the promoter's address during the sampling, which conditions the decision to stop at the sampling stand. The objective is to specify in details the behaviour of customers in case of address or lack of speech by the promoter. It is based on the claims of the authors Biswas et al. (2014) and Danaher (2017) who affirm that the success of sampling depends in a large extent on the active participation of the promoter. Similarly, the authors state that in case of the absence of the developer, its efficiency significantly reduces.

$82.44 \%$ of respondents do not stop and continue shopping, which presents a very high number. If the promoter does not address the passing customers, only $17.56 \%$ of respondents answered they stopped at the sampling stand (Table 3). On their initiative, only a tiny percentage of customers attend sampling. Based on these findings, only every fifth unaddressed customer would participate in sampling.

Table 3. Answers of the customers (Q3)

\begin{tabular}{|c|c|}
\hline Type of answer on question No. 3 & Number of answers \\
\hline I stop & 85 \\
\hline I do not stop and move on & 399 \\
\hline
\end{tabular}

Sources: own editing based on primary data collection.

The address of the promoter has become a key element to attract a customer, to at least stop at the sampling stand. From this point of view, based on theoretical knowledge, a promoter must be a communicative person to create interaction with the customer. These results have confirmed the hypothesis $\mathrm{H} 3$.

In the field of sampling perception by customers, which was evaluated using three questions in the questionnaire, Pearson's chi-square testing showed specific dependencies between individual variables - 
demographic data of respondents (gender and age) and questions related to the area. The following dependencies were found:

a) dependence between gender and decision to stop at the sampling stand without being addressed;

b) dependence between age and decision to stop at the sampling stand without being addressed.

$9 \%$ more men stay at the sampling stands even without being directed by a promoter (Table 4). Job position of a developer is mainly performed by women in the age category 18 - 30 years, what can be a prerequisite of the interest to stop even without being addressed first.

Table 4. Gender vs. stop at the sampling stand without address by a promoter

\begin{tabular}{|c|c|c|}
\hline Gender & I stop & $\begin{array}{c}\text { I do not stop and move } \\
\text { on }\end{array}$ \\
\hline Male & $23 \%$ & $76 \%$ \\
\hline Female & $14 \%$ & $85 \%$ \\
\hline
\end{tabular}

Sources: own editing based on primary data collection

The data are listed in descending order in the column "I do not stop and move on" for better illustration of the age influence on the decision not to stop at the sampling stand without being addressed by a promoter. From the table results that as the age of the respondents' increases, the willingness to stay without being also sent improvements, which has also been confirmed by the result of the Chi-square test (Table 5).

Table 5. Age vs. stop at the sampling stand without address by a promoter

\begin{tabular}{|c|c|c|}
\hline Age category & I stop & I do not stop and move on \\
\hline $18-25$ & $10 \%$ & $90 \%$ \\
\hline $26-35$ & $19 \%$ & $81 \%$ \\
\hline $36-50$ & $26 \%$ & $73 \%$ \\
\hline 50 and more & $28 \%$ & $72 \%$ \\
\hline 18 and less & $25 \%$ & $75 \%$ \\
\hline
\end{tabular}

Sources: own editing based on primary data collection.

The behaviour of the customer can be conditioned by the lifestyle of young people who are currently not as communicative as the older generation. Younger respondents prefer initial initiative of promoter instead of their action. According to Howe and Strauss (2007), Josiam et al. (2009) and Meister and Willyerd (2010), who defined the generation Y (generally born in the years 1980-2000), their communication level is strongly affected by the impact of modern technologies. They prefer sending emails and texting messages instead of face-to-face communication. They spend a big part of their lives online. There is a general conclusion - what is not on social networks, does not exist for these people. It significantly impacts companies by creating comprehensive sampling models. A manual for Generation $Y$ is based on digital addressing, and at the same time, it is necessary to keep online conversation because the mere addressing is not enough. This group of people requires an individual approach (Korcsmaros et al., 2019; Howe and Strauss, 2007; Josiam et al., 2009; Meister and Willyerd, 2010).

The second part of the survey focuses on the experience of the customers with unethical requirements of promoters. In the area of sampling ethics, it is surveyed whether the customers were repeatedly asked to taste even though they refused once. At the same time, whether they experienced pressure from the promoter to buy the sampled product. In both cases, the hypotheses were formulated under the 
assumption of keeping ethical principles during the product promotion process using sampling. From the customers' point of view, it is monitored whether they truthfully answer the question about the taste of the product if they just did not like it. It is necessary to follow the ethics and truthfulness of the customer responses because from a simple reason, strictly specified by proper promoters of sampling. The reactions of the customers on the offered products and their opinions are recorded in the forms (daily reports) that the promoters submit after realisation of sampling. This information is further processed and evaluated. It serves as a basis for future innovation and product improvements.

Q4: Have you ever been repeatedly asked to taste a product after you have refused?

The question (Q4) solves the hypothesis $\mathrm{H} 4$. It is based on the knowledge of the authors Lusnakova et al. (2011), Brinkmann (2002) and Butoracova (2009), who states that the company marketing is the most criticized because it is the most exposed to the public opinion. Concerning the sampling, the paper implements knowledge about marketing and ethics. Most companies incline to the exaggerated effort to persuade customers about excellent properties and a need to buy the product. However, the authors at the same time add that the company marketing activities should harmonize relationships and interests of the interested parties, while they maintain the ethical marketing principles, which is the prerequisite for the long-term success.

Majority of the respondents, $70.87 \%$ expressed that promoters did not repeatedly ask them to taste a product if then once refused. The assumed hypothesis $\mathrm{H} 4$ has been confirmed. On the other hand, $29.13 \%$ of respondents have experienced pressure from promoters or company providing the product promotion using a sampling, which is an alarmingly high number (Table 6).

Table 6. Answers of the customers (Q4)

\begin{tabular}{|c|c|}
\hline Type of response on question No. 4 & Number of answers \\
\hline Yes, they asked & 141 \\
\hline No, they did not ask & 343 \\
\hline
\end{tabular}

Sources: own editing based on primary data collection.

Following the results of the answers to the question (Q6), Pearson's chi-square test observed the dependence between the experience with a repeated request on sampling and demographic data. In this case, the relationship between the age and the repeated application on sampling after prior refusal has been confirmed. (Table 7).

Table 7. Age vs. repeated request to taste a product after prior refusal

\begin{tabular}{|c|c|c|}
\hline Age category & Yes, they asked & No, they did not ask \\
\hline $18-25$ & $23 \%$ & $77 \%$ \\
\hline $26-35$ & $40 \%$ & $60 \%$ \\
\hline $36-50$ & $33 \%$ & $67 \%$ \\
\hline 50 and more & $44 \%$ & $56 \%$ \\
\hline 18 and less & $28 \%$ & $72 \%$ \\
\hline
\end{tabular}

Sources: own editing based on primary data collection.

Mainly respondents in higher age category face the experience with repeated request on sampling. This fact is considered unethical, mostly because these people can easily undergo manipulation and they are not as cautious as people of younger age. It is not regarded as ethical that older people face these requests more often, especially in the relationship with the following results that concern another solved question.

Q5: Have you ever met with pressure by the promoter to buy the tasted product? 
The question (Q5) solves the sampling ethics with the emphasis on the experience with a pressure to buy the tasted product. The subject of interest is the specific experience of customers with the pressure exerted on the purchase of the product because they felt the offered product. In this field, the level of sampling ethics is manifested mostly, which is the subject matter of this paper. Based on the principles of ethical behaviour, the assumption of hypothesis $\mathrm{H} 5$ shall be confirmed. As the authors, Menovsky (2015), Boulstridge and Carrigan (2000), Low and Davenport (2009) state, the code of conduction determines a moral duty in the field of human activity, which is closely related to the ethical responsibility of the enterprise. At the same time, the authors Cariigan and Attalla (2001) claim, based on the results of their contributions, that the purchasing decisions of customers are greatly influenced by the level of ethical behaviour of the society.

The hypothesis $\mathrm{H} 5$ has been confirmed, as the majority of respondents $-80.17 \%$, have not experienced a pressure to buy the tasted product. On the other hand, the rest nearly $20 \%$ of respondents have ever met with force by promoters to buy the promoted product. (Table 8). When the customer refuses to buy a product once, it is not correct to be forced to do so. In this case, the Pearson's chi-square test showed a dependence between the age and pressure to buy the tasted product.

Table 8. Answers of the customers (Q5)

\begin{tabular}{|c|c|}
\hline Type of answer on question No. 5 & Number of questions \\
\hline Yes, I have & 96 \\
\hline No, I haven't & 388 \\
\hline
\end{tabular}

Sources: own editing based on primary data collection.

Table 9 shows an interesting finding that was not assumed. Respondents in lower age categories experience the pressure to buy the tasted product more often than older respondents. It can be caused by the attitude of promoters who feel that younger customers would be not able to reject vigorously disproportionate requests. Another cause may be a lack of respect for young people and their opinions.

Table 9. Age vs. pressure of promoters to buy the tasted product

\begin{tabular}{|c|c|c|}
\hline Age category & Yes & No \\
\hline $18-25$ & $24 \%$ & $76 \%$ \\
\hline $26-35$ & $24 \%$ & $76 \%$ \\
\hline $36-50$ & $10 \%$ & $90 \%$ \\
\hline 50 and more & $11 \%$ & $89 \%$ \\
\hline 18 and less & $13 \%$ & $87 \%$ \\
\hline
\end{tabular}

Sources: own editing based on primary data collection.

Q6: If you do not like the tasted product, do you answer truthfully on the question about the taste?

Concerning question (Q6), the hypothesis $\mathrm{H} 6$ is assumed that the majority of respondents will answer truthfully on the question about taste. In the practice of marketing companies, it is essential to have in mind and to work with the following, as the authors Lusnakova et al. (2011) state, that it is necessary to point out various benefits of the offer and concentrate on what the customers are interested in. It is essential to know the opinions of the customers, to ask about their experience because sometimes the most unsatisfied customer give the best tips for improvements. Therefore, the hypothesis $\mathrm{H} 6$ is considered equally important.

A high percentage of respondents, up to $78.10 \%$ answer truthfully on the question about the taste, also in case they did not like the product. The assumed hypothesis $\mathrm{H} 6$ has been confirmed that the majority of customers behave ethically and response truthfully. Other respondents $(21.9 \%)$ answer falsely that 
they liked the product, but they did not. (Table 10.). In terms of percentage, this part of respondents is considerably big. In practice, such a distorted response can partially impair the effectiveness of the sampling and its outcome, since one of the promoters' task is to monitor and then report the customer information.

Table 10. Answers of the customer (Q6)

\begin{tabular}{|c|c|}
\hline Type of response on question No. $\mathbf{6}$ & Number of answers \\
\hline Yes, I respond truthfully & 378 \\
\hline No, I say I liked it & 106 \\
\hline
\end{tabular}

Sources: own editing based on primary data collection

Answers to questions about the taste can serve for subsequent decisions on the further development of food, flavours, ingredients and the like. After conducting Pearson's chi-square testing, the dependence between gender and the correct answer to the question about the taste of the product was shown (Table 11.).

Table 11. Gender vs. correct answer about the product taste

\begin{tabular}{|c|c|c|}
\hline Gender & Yes, I respond truthfully & No, I say I liked it \\
\hline Male & $72 \%$ & $28 \%$ \\
\hline Female & $81 \%$ & $19 \%$ \\
\hline
\end{tabular}

Sources: own editing based on primary data collection

Women are more honest in answering promoter questions and are not afraid, to tell the truth about the tested products. Our survey showed that, compared to women, $9 \%$ more men are insincere.

Survey results indicate that product sampling in the food chain is a popular sales promotion tool and customers perceive it as positive as the authors Danaher (2017), Kotler et al. (2007) and Vysekalova et al. (2014) claim. Tutle (2011), Pauwels and Weiss (2008) and Shiv and Nowlis (2004) state that the reason is the feeling to gain something exclusive and free of charge. At the same time, they add that sampling is more efficient and cheaper than traditional forms of advertising. Notte (2011) noted that customers are most price-sensitive and that this is the main advantage of free sampling. The promoter itself plays an essential role during the sampling. Biswas et al. (2014) and Danaher (2017) expressed similarly. Its task is to actively address customers, report new findings and especially present the product. If the promoter does not proactively address customers, only a small percentage of them will stop at the sampling stand on their initiative.

The paper also compares the results of Keller and Lehmann (2006). It suggests a challenge for the future in the field of product sampling to make them more engaging for the younger generations, since older generations participate mainly on their initiative. It is also interesting to note that $9 \%$ more men participate in the sampling even without being addressed by the promoter. It is striking to find out that almost a third of respondents have experienced a repeated request for tasting despite the initial refusal. The sense of sampling remains, as the authors Lusnakova et al. (2011), Brinkmann (2002) and Butorac (2009) state, to introduce a new product to customers, to get feedback to ensure innovative development, however not unethically persuade them to buy the product. The results of the survey show that customers are honest in providing feedback. In case they did not like the product, most of them answer truthfully. Like the authors Carrigan and Attalla (2001), the paper emphasizes that customers' purchasing decisions largely depend on the level of ethical behaviour of the society, respectively on the promoter itself during the sampling. Wadhwa at al. (2018), Biswas et al. (2010) and Nowlis and Shiv (2005) present that sampling is a useful sales promotion tool, which is confirmed by its popularity that the paper dealt with. Like Hoegg and Alba (2007), Elder and Krishna (2010) and Hein (2009) present, the document confirms that the taste 
of the product can largely influence the purchasing decision and thus proportionally influence the sampling efficiency. Lockshin and Knott (2009) present results of their study that there is up to $400 \%$ growth of sale of the promoted products during realisation of the sampling.

Conclusions. The objective of the paper was to find out, using the questionnaire survey determined for the participants of sampling in the shops, how they perceive the sampling and how they react in case they are addressed or not addressed by a promoter. At the same time, the level of the sampling ethics was surveyed, that involved these factors: repeated request to taste in case the customer initially refused, pressure by the promoter to buy the tasted product and correct answer on the question about the product taste if the customer did not like it. The paper contributes to the area of in-store marketing focusing on sampling in retail stores. It brings findings dedicated to the popularity of sampling in practice, shopping habits of customers and at the same time, it reveals a space for further improvements. It can be visible in the sampling ethics since it has been proven, that there are individual failures when requesting to participate in sampling and also in influencing customers in their purchasing decisions.

Author Contributions: Authors have an equal contribution for preparing the manuscript. For the conceptualization A K. and M. S., methodological issue by A.K. and M. Dz., analysis and investigation A. K., M. Dz. and M. S., resources A. K. and J. D., writing A. K., M. S. and M. Dz., revision M. S. and M. Dz., formatting A. K., M. S. and M. Dz. All authors have read and approved the final manuscript.

Funding: This research was funded by Slovak Research and Development Agency, grant number APVV-18-0520, APVV-18-0378, APVV-17-0456 and APVV-17-0583.

\section{References}

Aggerholm, H., Andersen, S. E., \& Thomsen C. (2011). Conceptualising employer branding in sustainable organizations. Corporate Communications: An International Journal. [Google Scholar] [CrossRef]

Alvarez, B. A., \& Casielles, R. (2005). Consumer evaluations of sales promotion: the effect on brand choice. European Journal of Marketing. [Google Scholar] [CrossRef]

Amor, I. B., \& Guilbert, F. (2015). The Effect Of Product Sampling On Brand Image. In Proceedings of the 2007 Academy of Marketing Science (AMS) Annual Conference (pp. 139-144). Springer, Cham. [Google Scholar] [CrossRef]

Bawa, K., \& Shoemaker, R. (2004). The effect of free-sample promotions on incremental brand sales. Marketing Science 23(3), 345-363. [Google Scholar] [CrossRef]

Biswas, D., Grewal, D., \& Roggeveen, A. (2010). How the order of sampled experiential products affects choice. Journal of Marketing 47(6), 508-519. [Google Scholar] [CrossRef]

Biswas, D., Labrecque, L. I., Lehmann, D. R., \& Markos, E. (2014). Making choices while smelling, tasting, and listening: The role of sensory (dis) similarity when sequentially sampling products. Journal of Marketing. 78(1), 112-126. [Google Scholar] [CrossRef]

Boulstridge, E., \& Carrigan, M. (2000). Do consumers really care about corporate responsibility? Highlighting the attitudebehaviour gap. Journal of Communication Management 4(4), 355-368. [Google Scholar] [CrossRef]

Brinkmann, J. (2002). Business and marketing ethics as professional ethics. Concepts, approaches and typologies Journal of Business Ethics 41(1-2), 159-177. [Google Scholar] [CrossRef]

Buil, I., De Chernatony, L., \& Martinez, E. (2013). Examining the role of advertising and sales promotions in brand equity creation. Journal of Business Research 66(1), 115-122. [Google Scholar] [CrossRef]

Butoracova, I. (2009). Eticke zasady a ich dominantne postavenie $v$ marketingovej praxi europskeho trhoveho prostredia. Marketing \& Komunikace 19(1), 10-12.

Carrigan, M., \& Attalla, A. (2001). The myth of the ethical consumer-do ethics mater in purchase behaviour? Journal of Consumer Marketing. [Google Scholar] [CrossRef]

Chandon, P., Wansink, B., \& Laurent, G. (2000). A benefit congruency framework of sales promotion effectiveness. Journal of Marketing 64(4), 65-81. [Google Scholar] [CrossRef]

Chen, L., Parcell, J. L., Chen, Ch., James Jr, H. S., Xu, D. (2016) Consumer preference for supermarket food sampling in China (No. 333-2016-14878). [Google Scholar]

Chen, W. (2013). The effects of different types of trust on consumer perceptions of food safety: An empirical study of consumers in Beijing Municipality, China. China Agricultural Economic Review, 5(1), 43-65. [Google Scholar] [CrossRef] 
Danaher, K. (2017). Product Sampling Marketing. Retrieved from: https://salespromotions.org/product-sampling-marketing/ Daniel, J. (2017). Marketingova komunikace v miste prodeje: POP, POS, in-store, shopper marketing. Grada Publishing as. [Google Scholar]

Dawes, J. (2002). Assessing the Impact of a Big Price Promotion on Brand, Category and Competitor Sales. (Doctoral dissertation, Deakin University). [Google Scholar]

Elder, R. S., Krishna, A. (2010). The effects of advertising copy on sensory thoughts and perceived taste. Journal of Consumer Research 36(5), 748-756. [Google Scholar] [CrossRef]

Ferrel, O. C., Hartline, M. (2007). Marketing Strategy. South-Western College Pub; $4^{\text {th }}$ edition, 2007. 744 p. ISBN 9780324362725

Hawkes, C. (2008). Agro-food industry growth and obesity in China: what role for regulating food advertising and promotion and nutrition labelling? Obesity Reviews 9, 151-161. [Google Scholar] [CrossRef]

He, J., Ji, Y. Q., \& Wu, H. J. (2005). Consumer behavior mode of fresh food-comparison of supermarket and free market of agricultural products. Journal of China Agricultural University (Social Sciences Edition), 3, 65-69. [Google Scholar]

Heilman, C. M., Lakishyk, K., \& Radas, S. (2011). An empirical investigation of in-store sampling promotions. British Food Journal 113(10), 1252-1266. [Google Scholar] [CrossRef]

Heiman, A., Williams, B., Shen, Z., \& Zilberman, D. (2001). Learning and forgetting: modeling optimal product sampling over time. Management Science 47(4), 532-546. [Google Scholar] [CrossRef]

Hein, K. (2009). Sampling Inspires Repeat Purchase. Adweek, (August 4), (accessed October 4, 2013) Retrieved from: https://www.adweek.com/brand-marketing/sampling-inspires-repeat-purchases-99961/

Hoegg, J., \& Alba, J. W. (2007). Taste perception: More than meets the tongue. Journal of Consumer Research 33(4), 490-498. [Google Scholar] [CrossRef]

Howe, N., \& Strauss, W. (2007). The next 20 years: how customer and workforce attitudes will evolve. Harvard Business Review 85(7-8), 41-52 [Google Scholar]

Josiam, B. M., Crutsinger, C., Reynolds, J. S., Dotter, T. V., Thozhur, S., Baum, T. \& Devine, F. (2009). An empirical study of the work attitudes of Generation Y college students in the USA: the case of hospitality and merchandising undergraduate majors. Journal of Services Research 9(1), 5-30. [Google Scholar]

Keller, K. L., \& Lehmann, D. R. (2006). Brands and branding: Research findings and future priorities. Marketing Science 25(6), 740-759. [Google Scholar] [CrossRef]

Kim, S. (2019.) The process model of corporate social responsibility (CSR) communication: CSR communication and its relationship with consumers' CSR knowledge, trust, and corporate reputation perception. Journal of Business Ethics 154(4), 11431159. [Google Scholar] [CrossRef]

Korcsmaros, E., Seben, Z., Machova, R., \& Feher, L. (2019). Promotion of Euro Introduction in Slovakia: Financial Literacy of Generation X and Y. Marketing and Management of Innovations 3, 11-21. [Google Scholar] [CrossRef]

Kotler, P., Wong, V., Saunders, J., Armstrong, G. (2007). Moderni marketing. ( 4th eur. vyd). Praha: Grada Publishing.

Kozel, R. (2006). Moderni marketingovy vyzkum. Praha: Grada Publishing, a.s. [Google Scholar]

Lammers, H. B. (1991). The effect of free samples on immediate consumer purchase. Journal of Consumer Marketing 8(2), 3137. [Google Scholar]

Laran, J., \& Tsiros, M. (2013). An investigation of the effectiveness of uncertainty in marketing promotions involving free gifts. Journal of Marketing 77(2), 112-123. [Google Scholar] [CrossRef]

Lusnakova, Z., Kleinova, K., Kubicova, L'. (2011). Ethics in Business Firms Activities. Etika v marketingovej komunikacii.

Retrieved from: http://www.slpk.sk/eldo/2011/zborniky/11-11/lusnakova kleinova kubicova.pdf

Lockshin, L., \& Knott, D. (2009). Boozing or branding? Measuring the effects of free wine tastings at wine shops. International Journal of Wine Business Research. [Google Scholar] [CrossRef]

Low, W., \& Davenport, E. (2009). Organizational leadership, ethics and the challenges of marketing fair and ethical trade. Join of Business Ethics 86(1), 97-108. [Google Scholar] [CrossRef]

Mandal, K., \& Banerjee, S. (2018). Responsible Marketing and Its Impact on Business Performance: A Longitudinal Study. Journal of Nonprofit \& Public Sector Marketing, 31(2), 115-138. [Google Scholar] [CrossRef]

McGuiness, D., Brennan, M., \& Gendall, P. (1995). The effect of product sampling and couponing on purchase behaviour: some empirical evidence. International Journal of Advertising, 14(3), 219-230. [Google Scholar] [CrossRef]

McNeill, L. S. (2006). The influence of culture on retail sales promotion use in Chinese supermarkets. Australasian Marketing Journal 14(2), 34-46. [Google Scholar] [CrossRef]

Meister, J.C., \& Willyerd, K. (2010). Spotlight on leadership: The next generation - mentoring millennials. Harvard Business Review 1(1), 1-5.

Meler, M., \& Dragan, M. (2014). Sustainable Marketing for Sustainable Development. In 11th International Academic Conference Reykjavik. [CrossRef]

Menovsky, I. (2015). Eticky kodex ako nastroj budovania podnikovej kultury. Retrieved from: https://www.epi.sk/odbornyclanok/Eticky-kodex-ako-nastroj-budovania-podnikovej-kultury.htm

Ndubisi, N. O., Fam, K. S., Merrilees, B., Richard, J. E., Jozsa, L., Li, Y., \& Krisjanous, J. (2011). In-store marketing: a strategic perspective. Asia Pacific Journal of Marketing and Logistics. [Google Scholar] [CrossRef] 
Notte, J. (2011) Why Retailers Pay For Your Free Samples. Retrieved from: https://www.thestreet.com/personal-finance/whyretailers-pay-for-your-free-samples-11008255

Nowlis, S. M., \& Shiv, B. (2005). The influence of consumer distractions on the effectiveness of food-sampling programs. Journal of Marketing Research, 42(2), 157-168. [Google Scholar] [CrossRef]

Pauwels, K., \& Weiss, A. (2008). Moving from free to fee: How online firms market to change their business model successfully. Journal of Marketing 72(3), 14-31. [Google Scholar] [CrossRef]

Pride, W. M., Ferrell, O. C. (2006). Marketing: Concepts and Strategies. Cincitani, Ohio: South-Western College Pub.

Range, J., \& Leonard, A. (2016, September) LAYERS: The link between governance and self-service technology in supporting trust within fresh produce markets in South Africa. In Proceedings of the Annual Conference of the South African Institute of Computer Scientists and Information Technologists (pp. 1-8). [Google Scholar] [CrossRef]

Sadiku, M. N., Ashaolu, T. J., \& Musa, S. M. (2019). Food Marketing. A primer. [Google Scholar]

Seretny, M., \& Seretny, A. (2012). Sustainable marketing-a new era in the responsible marketing development. Foundations of Management 4(2), 63-76. [Google Scholar] [CrossRef]

Shiv, B., \& Nowlis, S. M. (2004). The effect of distractions while tasting a food sample: The interplay of informational and affective components in subsequent choice. Journal of Consumer Research 31(3), 599-608. [Google Scholar] [CrossRef]

Tutle, B. (2011). The power of freebies: Why companies pay to give free samples to supermarket customers. Retrieved from http://business.time.com/2011/02/17/the-power-of-freebies-why-companies-pay-to-give-free-samples-to-supermarket-customers/

Vetrakova, M., Hitka, M., Potkany, M., Lorincova, S., \& Smerek, L. (2018). Corporate sustainability in the process of employee recruitment through social networks in conditions of Slovak small and medium enterprises. Sustainability 10(5), 1670. [Google Scholar] [CrossRef]

Vysekalova, J (2014). Emoce v marketing. Praha: Grada Publishing. [Google Scholar]

Wadhwa, M., Shiv, B., \& Nowlis, S. M. (2018). A bite to whet the reward appetite: The influence of sampling on reward- seeking behaviors. Journal of Marketing 45(4), 403-413. [Google Scholar] [CrossRef]

Маряна Седлячикова, Ph.D., доцент, Технічний університет у Зволені (Словаччина);

Анна Кочіянова, Технічний університет у Зволені (Словаччина);

Міхал Дзян, Ph.D., Технічний університет у Зволені (Словаччина);

Йозеф Драбек, доцент, Технічний університет у Зволені (Словаччина).

Дегустація продуктів харчування як інструмент стимулювання збуту

у статті проаналізовано та систематизовано маркетингові інструменти промоції у роздрібній торгівлі продуктів харчування. Авторами зазначено, що найбільш ефективним маркетинговим інструментом активізації роздрібної торгівлі продуктів харчування $є$ проведення дегустацій. Метою статті $\epsilon$ аналіз сприйняття клієнтами торгових мереж Словаччини проведення дегустацій, як інструменту промоції продуктів харчування. Ефективність проведення дегустацій було перевірено на основі кількості звернень клієнтів торгових мереж до промоутера під час проведення дегустації. При цьому до уваги приймались етичні аспекти поведінки клієнтів та промоутера, як головного представника бренду продукту. Під час проведення експерименту було зафіксовано кількість повторних запитів на дегустацію від одного й того ж клієнта. Авторами наголошено, що у ході дослідження було проведено онлайн-анкетування 484 клієнтів щодо їх вподобань до смаку та якості товару. Результати анкетування засвідчили позитивне ставлення клієнтів торгової мережі до проведення дегустацій як інструменту промоції продуктів харчування. У статті наголошено, що проведення дегустацій не поширені у Словаччині, що тим самим обмежує використання потенціалу комунікації між споживачами та виробниками продуктів харчування. Авторами підкреслено, що при проведенні дегустацій промоутер є не лише найманим працівником, але й представником бренду продукту, а ефективність проведення відповідних рекламних акцій залежить від комунікативних здібностей промоутера. Результати дослідження дозволили виокремити основні фактори-впливу на дотримання принципів етики клієнтами під час проведення дегустацій, а саме: вік та стать. Так, встановлено, що жінки більш схильні давати відповідь та комунікувати $з$ промоутером під час дегустацій. Визначено, що нещирих респондентів чоловічої статті на 9\% більше ніж жіночої. Авторами наголошено, що результати дослідження можуть бути використані менеджерами та маркетологами торгових мереж при формуванні стратегії промоції продуктів харчування. Окрім цього отримані дані щодо етичних аспектів поведінки споживачів, їх вподобань та звичок доцільно врахувати при проведенні подальших досліджень.

Ключові слова: дегустація, етика дегустації, клієнти, промоутер, сприйняття дегустацій.

Manuscript received: 19.12.2019.

(C) The author(s) 2020. This article is published with open access at Sumy State University. 